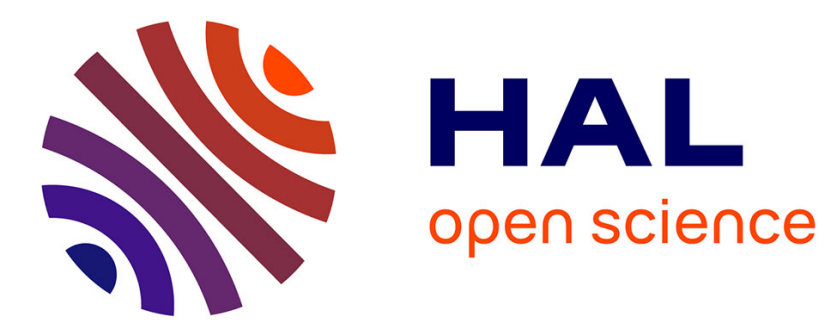

\title{
Evolution in the Anthropocene
}

F. Sarrazin, J. Lecomte

\section{To cite this version:}

F. Sarrazin, J. Lecomte. Evolution in the Anthropocene. Science, 2016, 351 (6276), pp.922-923. 10.1126/science.aad6756 . hal-01284574

\section{HAL Id: hal-01284574 https://hal.sorbonne-universite.fr/hal-01284574}

Submitted on 7 Mar 2016

HAL is a multi-disciplinary open access archive for the deposit and dissemination of scientific research documents, whether they are published or not. The documents may come from teaching and research institutions in France or abroad, or from public or private research centers.
L'archive ouverte pluridisciplinaire HAL, est destinée au dépôt et à la diffusion de documents scientifiques de niveau recherche, publiés ou non, émanant des établissements d'enseignement et de recherche français ou étrangers, des laboratoires publics ou privés. 


\section{Evolution in the Anthropocene}

By François Sarrazin ${ }^{1}$ and Jane Lecomte ${ }^{2}$

${ }^{1}$ Sorbonne Universités, UPMC Univ Paris 06, Muséum National d'Histoire Naturelle, CNRS, CESCO, UMR 7204, 75005 Paris, France.

${ }^{2}$ Ecologie Systématique Evolution, Univ. Paris-Sud, CNRS, AgroParisTech, Université Paris-Saclay, 91400 Orsay, France.

E-mail: sarrazin@mnhn.fr

Taking account of the evolutionary effects of human actions is crucial for humans and nonhumans

Most current conservation strategies focus on the immediate social, cultural, and economic values of ecological diversity, functions, and services (1). For example, the Intergovernmental Platform on Biodiversity and Ecosystem Services (2) mostly addresses the utilitarian management of biodiversity from local to global scales. However, besides urgent diagnosis and actions $(3,4)$, processes that occur over evolutionary time scales are equally important for biodiversity conservation. Strategizing for conservation of nature at such long time scales will help to preserve the function-and associated services-of the natural world, as well as providing opportunities for it to evolve. This approach will foster a long-term, sustainable interaction that promotes both the persistence of nature and the wellbeing of humans.

Considering the evolutionary trajectories of nonhumans beyond human interest may also constitute a major evolutionary transition (5). It would be the first case in the history of life on Earth where a species cares for the evolution of other species beyond its own fitness and well-being.

Most conservation actions aim to protect particular populations, species, communities, ecosystems, or ecosystem services. Although these actions target important current issues, they also affect the evolutionary trajectories of these systems in various, generally unplanned ways. For many taxonomic groups, such as primates or island birds, anthropogenic extinctions are not phylogenetically random (6). Further, extinctions and population size reductions may greatly constrain the evolutionary trajectories not only of the target species, but also of other members of the community or ecosystem. Such unintended changes occur, for example, through extinction cascades (6), changes in direct and indirect selective pressures on genetic and phenotypic diversity, and alteration of interaction networks and coevolutionary networks. These consequences are rarely considered when 
actions are taken to preserve or promote specific ecosystem services (7). We thus know very little about how our current focus on such services will affect long-term ecosystem function, composition, and stability.

In agriculture, domestication syndrome is a tangible example of how a focus on one or a few specific desirable components of a species or system can have unexpected evolutionary consequences. In this syndrome, a consistent set of morphological traits (such as reduced brain size in animals or nonshattering seeds in plants) can emerge as a result of selection for a different set of desired traits. Thus, active selection of specific desired traits causes the retention of not only those traits, but a suite of other traits that are both unintended and currently outside of human control.

We expect a similar process to occur as we begin to enact larger-scale selection on nature for specific purposes. This is critical for the intensive exploitation of biodiversity by humans (8). Some naturebased solutions set up to mitigate the effects of climate change- such as planting forests for carbon storage, using biomass to produce green energy, or protecting coastal wetlands to adapt to rising sea levels-are also likely to change local ecological selection regimes, causing shifts in evolutionary trajectories. Cultural and recreational services may similarly shape evolutionary trajectories by defining particular strategies of rewilding, restoring, and perhaps even resurrecting extinct species (9).

Finally, advances in synthetic biology and genetic engineering are likely to lead to the emergence of new types of organisms, including some designed for environmental engineering. This particular strategy would open up an especially worrying "Pandora's box" of novel genetic and ecological interactions. Although we can manage the desirable traits or target functions of species and ecosystems, control of the evolutionary consequences of such actions is not within our power. It is therefore essential to explore how nature can be conserved for maximum evolutionary freedom.

All life, both human and nonhuman, is a product of evolution. Through evolutionary luck and niche construction, humans have reached a point where our quest for well-being goes beyond the requirements of survival and reproduction (i.e., beyond evolutionary fitness). Humans also assign intrinsic values to entities that have their own ends, and they assign instrumental values to entities that are means to achieve other ends (10).

Thinking about both humans and nonhumans within this kind of evolutionary and ethical framework allows us to address basic questions about different conservation scenarios (see the figure). Should we abandon attempts at biodiversity conservation? This scenario would mean pursuing a human evolutionary trajectory that ignores nonhumans in a blind Anthropocene-a choice sure to have many unintended consequences (11).

Alternatively, do we conserve biodiversity for the resilience of human generations, either for the immediate well-being of human individuals or for the well-being of future generations? In these scenarios, we place instrumental value only on specific, desired traits of nature-again with unintended and unknown consequences.

Finally, do we conserve biodiversity for the wellbeing of future human generations as well as nature? In ecological systems, the well-being of nonhumans is mostly driven by their fitness. Conservation for people and nature (1) must then rely not only on intrinsic values of human well-being and fitness, but also on nonhuman fitness. It requires an interspecific form of altruism to achieve neutrality on nonhuman evolutionary trajectories, whatever our genetic distance toward nonhumans, the services we expect from them, their beauty, or our need for nature. Such evolution-focused or "evocentric" conservation could be part of a deliberate overcoming of the Anthropocene (see the figure).

The aim to conserve the evolutionary potential of nonhumans has many consequences. It requires us to define operational metrics of evolutionary potential that account for phylogenetic diversity and 
evolutionary distinctiveness (6); genetic, functional, and cultural diversity within populations; and networks of interactions within communities and ecosystems.

To make progress toward these goals, we must remember that biodiversity and ecosystem functioning support evolutionary processes, and not the opposite. Furthermore, it is crucial that we view adaptation to global change as a necessary means of enabling the potential evolution of nonhumans (and not merely a means of adapting natural systems solely to short-term human ends). The deliberate creation and stewardship of evolutionary trajectories through synthetic biology or genetic engineering should not be used to replace native life forms or affect their evolution, but only as a very last resort to reduce our evolutionary impacts on them. To reduce the spatial and temporal extent of human directional selective pressures, it is also important to maintain and restore wildness wherever possible, even outside areas of pristine wilderness.

Reducing the increasing rate at which human activities perturb nonhuman dynamics is a prerequisite to evocentric conservation (see the photo). Indeed, generation times constrain the speed of adaptive responses of most species and populations, particularly of long-lived and specialist ones. Conserving nonhuman evolutionary potential therefore requires a fundamental shift in the burden of proof from "why conserve?" to "why destroy?" biodiversity.

Many stakeholders and conservationists consider conservation for nature itself as outdated, utopian, or inefficient. They advocate a "new conservation" dedicated to people (12). However, at the scale of evolution, considering other life forms as resources-even in a broad sense-is not innovative. The deliberate conservation of the evolutionary potential and opportunity of nonhumans beyond the services they provide us with is, by contrast, a real novelty. It forces us to think about links between human and nonhuman evolutionary trajectories and reduces the focus on a trade-off between longterm human well-being and wildness (see the figure).

What we conserve defines what we are or pretend to be. We must establish and promote comprehensive dialogs among social scientists, ecologists, and evolutionary biologists to explore the biological and cultural roots of our interactions with nonhumans and to understand the origins of our inertia in the face of the urgency of biodiversity erosion. Addressing this major challenge for humanity may also enhance our ability to respect each other in our societies.

\section{REFERENCES}

1. G. M. Mace, Science 345, 1558 (2014).

2. S. Díaz et al., Curr. Opin. Environ. Sustain. 14, 1 (2015).

3. A. D. Barnosky et al., Nature 471, 51 (2011).

4. S. L. Pimm et al., Science 344, 1246752 (2014).

5. E. Clarke, J. Biosci. 39, 303 (2014).

6. S. Veron, T. J. Davies, M. W. Cadotte, P. Clergeau, S. Pavoine, Biol. Rev. 10.1111/brv.12228 (2015).

7. D. P. Faith et al., Curr. Opin. Environ. Sustain. 2, 66 (2010).

8. C. T. Darimont, C. H. Fox, H. M. Bryan, T. E. Reimchen, Science 349, 858 (2015).

9. P. J. Seddon, C. J. Griffiths, P. S. Soorae, D. P. Armstrong, Science 345, 406 (2014).

10. J. A. Vucetich, J. T. Bruskotter, M. P. Nelson, Conserv. Biol. 29, 321 (2015).

11. W. Steffen et al., Science 347, 1259855 (2015).

12. R. T. Corlett, Trends Ecol. Evol. 30, 36 (2015). 


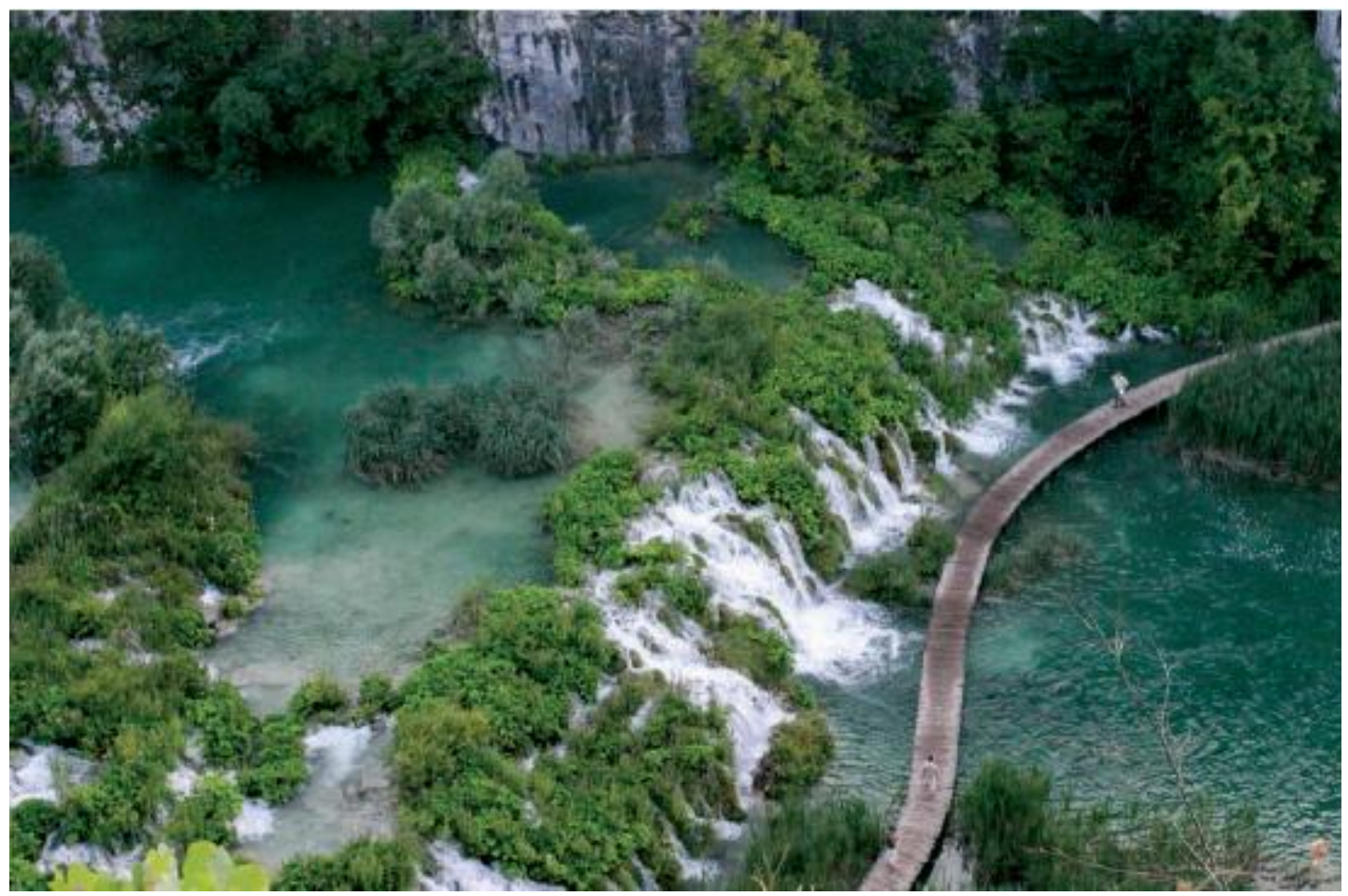

Treating nature with respect. Human-made structures that protect natural interactions reduce the impact of human visitors on biodiversity in the Plitvice Lakes National Park, Croatia.

Evolutionary roots, challenges, and consequences of conservation strategies and ethics

\begin{tabular}{|c|c|c|c|c|c|c|c|}
\hline \multirow[b]{2}{*}{ SHOULD WE ... } & \multicolumn{3}{|l|}{ Roots } & \multicolumn{2}{|l|}{ Challenges } & \multicolumn{2}{|c|}{ Consequences } \\
\hline & INTRINSIC VALUE & CONSERVATION & WILDERNESS & $\begin{array}{l}\text { ECOSYSTEM } \\
\text { SERVICES (ES) }\end{array}$ & & $\begin{array}{r}\text { EVOLUTIO } \\
\text { TRANSITIONS }\end{array}$ & $\begin{array}{l}\text { NARY } \\
\text { IMPACTS }\end{array}$ \\
\hline $\begin{array}{l}\text { abandon attempts } \\
\text { at biodiversity } \\
\text { conservation? }\end{array}$ & None & None & None & $\begin{array}{l}\text { Runaway } \\
\text { consumption } \\
\text { of biodiversity } \\
\text { resources }\end{array}$ & $\begin{array}{l}\text { Blind } \\
\text { Anthropocene }\end{array}$ & Minor & Major \\
\hline $\begin{array}{l}\text { conserve for the } \\
\text { resilience of } \\
\text { future human } \\
\text { generations? }\end{array}$ & Human fitness & 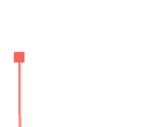 & None & $\begin{array}{l}\text { Long-term } \\
\text { provisioning } \\
\text { and regulating } \\
\text { ES }\end{array}$ & & & \\
\hline $\begin{array}{l}\text { conserve for the } \\
\text { immediate well-being } \\
\text { of human individuals? }\end{array}$ & Human well-being & Anthropocentric & $\begin{array}{l}\text { Scenic } \\
\text { wilderness }\end{array}$ & $\begin{array}{l}\text { Short-term } \\
\text { provisioning } \\
\text { and cultural } \\
\text { ES }\end{array}$ & $\begin{array}{l}\text { Deliberate } \\
\text { Anthropocene }\end{array}$ & & \\
\hline $\begin{array}{l}\text { conserve for the } \\
\text { well-being of future } \\
\text { human generations? }\end{array}$ & $\begin{array}{l}\text { Human well-being } \\
\text { and fitness }\end{array}$ & 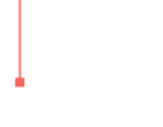 & $\begin{array}{l}\text { Scenic } \\
\text { wilderness }\end{array}$ & $\begin{array}{l}\text { Long-term } \\
\text { provisioning, } \\
\text { regulating, and } \\
\text { cultural ES }\end{array}$ & & & \\
\hline $\begin{array}{l}\text { conserve for the } \\
\text { well-being of future } \\
\text { human generations } \\
\text { and nature? }\end{array}$ & $\begin{array}{l}\text { Human well-being } \\
\text { and fitness } \\
\text { Nonhuman fitness }\end{array}$ & Evocentric & $\begin{array}{l}\text { Wildness } \\
\text { beyond } \\
\text { wilderness }\end{array}$ & $\begin{array}{l}\text { Long-term } \\
\text { evolutionary } \\
\text { trajectories } \\
\text { beyond ES }\end{array}$ & $\begin{array}{l}\text { Deliberate } \\
\text { overcoming } \\
\text { of the } \\
\text { Anthropocene }\end{array}$ & Major & Minor \\
\hline
\end{tabular}

